\title{
Expression patterns of heat shock genes during population dynamics of the rotifer Brachionus plicatilis
}

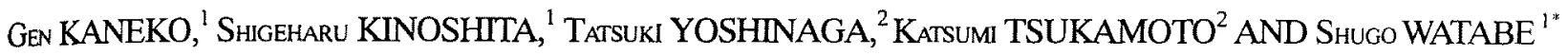 \\ ${ }^{1}$ Laboratory of Aquatic Molecular Biology and Biotechnology, Graduate School of Agricultural and \\ Life Sciences, The University of Tokyo, Tokyo 113-8657, Japan (awatabe@mail.ecc.u-tokyo.ac.jp) and \\ ${ }^{2}$ Ocean Research Institute, The University of Tokyo, Nakano, Tokyo 164-8639, Japan
}

KEY WORDS: Brachionus plicatilis, GRP94, HSP70, lifespan, rotifer, ubiquitin-conjugating enzyme.

\section{INTRODUCTION}

Due to their short lifespan and fertility rotifers have been used as a model organism in ecology and gerontology. ${ }^{1)} \quad$ Yoshinaga et $a l^{2}$ ) demonstrated that the population dynamics of the rotifer Brachionus plicatilis shows a typical sigmoid curve. Under starved conditions in the stationary phase, individuals reduce their lifetime fecundity and prolong lifespan and reproductive period to maintain a stable population. This suggests that rotifers can control their lifespan to adapt themselves to various environmental conditions. Although such a trade-off between lifespan and reproduction is found in various species, the underlying molecular mechanisms are still unclear. To cope with such ambiguities, we cloned the rotifer HSP70, GRP94 and ubiquitin-conjugating enzyme (E2), which have been suggested to prolong lifespan of fruit fly ${ }^{3)}$ and yeast, ${ }^{4)}$ and further examined for phase-specific expression patterns.

\section{MATERIALS AND METHODS}

We used a clonal Brachionus plicatilis established from a single amictic female of the Ishikawa strain. ${ }^{5)}$ The rotifers were cultured in Brujewicz artificial seawater (BAS) at $25 \mathrm{C}$, under total darkness except feeding time. The feeding algae (Nannochloropsis oculata) was suspended in the medium at $7 \times 10^{6}$ cells/mL. Rotifers were collected through filtration on days 10 (exponential phase) and 15 (stationary phase) after inoculation of 10 rotifers bearing 3-4 eggs into $400 \mathrm{~mL}$ BAS following which total RNA were extracted using ISOGEN solution (Nippon Gene). Poly $(\mathrm{A})^{+}$RNA was fractionated using Oligotex-dT30 super (Takara).

First strand cDNA was synthesized as follows. An aliquot of $1 \mu \mathrm{g}$ total RNA prepared each from the exponential and stationary phases was dissolved in $12 \mu \mathrm{L}$ water and heated at $70 \mathrm{C}$ for $10 \mathrm{~min}$, then quickly chilled on ice before synthesis. The NotI oligo dT primer was used at $50 \mu \mathrm{g} / \mathrm{mL}$ to initiate first strand cDNA synthesis with $0.5 \mathrm{U}$ Superscript II reverse transcriptase (Gibco BRL) in a buffer containing $50 \mathrm{mM}$ Tris-HCl (pH 8.3), $75 \mathrm{mM} \mathrm{KCl}, 3 \mathrm{mM} \mathrm{MgCl}_{2}, 500 \mathrm{mM}$ dNTP, and $10 \mathrm{mM}$ DTT. The reaction was carried out at $42 \mathrm{C}$ for $1 \mathrm{~h}$ in total $20 \mu \mathrm{L}$ and then the enzyme was heat-inactivated at $70 \mathrm{C}$ for $15 \mathrm{~min}$. Ten $\mu \mathrm{g}$ of RNase $\mathrm{H}$ was then added to remove RNA templates.

Degenerate primers of HSP70F1 and HSP70R 1 for HSP70, rGRPF1 and rGRPR 1 for GRP94, and rE2F1 and rE2F2 for ubiquitin-conjugating enzyme were designed with reference to DNA nucleotide sequences from various species (GenBank accession number XM_004189, U09861, M76613, AB062281, AJ001312 for HSP70; AF012437, M10051 for GRP94; and AF020344, AF114261, AF032885 for ubiquitin-conjugating enzyme). PCR consisted of 30 cycles of denaturation at $94 \mathrm{C}$ for $30 \mathrm{~s}$, annealing at $55 \mathrm{C}$ for HSP70 and GRP94 or $42 \mathrm{C}$ for ubiquitin-conjugating enzyme for $30 \mathrm{~s}$, and polymerization at $72 \mathrm{C}$ for $1 \mathrm{~min}$, with a final polymerization step at $72 \mathrm{C}$ for $5 \mathrm{~min}$. The composition of the reaction mixture was according to manufacturer's protocol using $1 \mathrm{U}$ Ex Taq DNA polymerase (Takara). The amplified products were subcloned into the pGEM-T Easy Vector (Promega) and sequenced from both $5^{\prime}$ and $3^{\prime}$ strands using primers complementary to vector arms with Dye Deoxy ${ }^{\mathrm{TM}}$ terminator cycle sequencing kit using a DNA sequencer model 373S (Applied Biosystems). Sequence homology was analyzed using BLAST search.

For Northern blot analysis, $10 \mu \mathrm{g}$ of total RNA, prepared each from rotifers in exponential and stationary phases were 
resolved in electrophoresis on a $0.9 \%$ agarose gel containing $0.44 \mathrm{M}$ formamide and blotted onto a Hybond $\mathrm{N}^{+}$nylon membrane (Amersham). The membrane was baked at $120 \mathrm{C}$ for $20 \mathrm{~min}$, then prehybridized in a solution containing $0.5 \mathrm{M} \mathrm{Na} \mathrm{HPO}_{4}$ (pH 7.2), $1 \mathrm{mM}$ EDTA, and $7 \%$ sodium dodecyl sulfate (SDS) at $65 \mathrm{C}$ for $5 \mathrm{~min}$. Hybridization was performed at $65 \mathrm{C}$ for $16 \mathrm{~h}$ in the same solution containing cDNA probes described below. The membrane was washed with $1 \times$ SSC $(0.15$ $\mathrm{M} \mathrm{NaCl}, 15 \mathrm{mM}$ sodium citrate, $\mathrm{pH} 7.0$ ) containing $0.1 \%$ SDS for $20 \mathrm{~min}$ at room temperature and subsequently with the same buffer at $65 \mathrm{C}$ for $20 \mathrm{~min}$, then exposed to $\mathrm{X}$-ray films at $-80 \mathrm{C}$ for $24 \mathrm{~h}$. The hybridized membrane was scanned with a Fujix BAS 1000 computerized densitometer scanner and quantified using a recommended scanning program. cDNA fragments amplified by RT-PCR for rotifer HSP70, GRP94 and ubiquitin-conjugating enzyme were used as probes. Twenty $n g / \mu \mathrm{L}$ of the fragments were labeled with $\left[\alpha^{32}-\mathrm{P}\right]$ dCTP using Takara random primer DNA labeling kit Ver. 2 (Takara).

\section{RESULTS AND DISCUSSION}

cDNA fragments encoding rotifer HSP70, GRP94 and ubiquitin-conjugating enzyme were successfully cloned by PCR amplifications using primers described before (GenBank accession number AB076052, AB076053 and AB076054, respectively). Three lots of total RNA were extracted each from rotifers in the exponential and stationary phases and subjected to Northern blot analysis for HSP70, GRP94 and ubiquitin-conjugating enzyme. The mRNA accumulated levels of HSP70 and GRP94 in the exponential phase were 2.5 and 1.6 times higher, respectively, than those in the stationary phase, whereas the levels of ubiquitin-conjugating enzyme did not differ between the two phases.

Expression of stress proteins induced by several origins has been claimed to be associated with lifespan extension beside their participation in refolding or selective degradation of denatured proteins. In transgenic fruit fly Drosophila melanogaster with increased copy numbers of the $h s p 70$ gene, nonlethal heat-treatments induced HSP70 protein to levels greater than $30 \%$ of wild-type control and prolonged life expectancy. ${ }^{3)}$ In this study, the accumulated mRNA levels of HSP70 and GRP94 in the exponential phase were higher than those in the stationary phase, indicating that expression of these stress proteins are not directly related to the extension of lifespan in the stationary phase. An alternate explanation may be derived from the fact that populations in the exponential phase consisted of mainly immature and young adult females, whereas those in the stationary phase consisted of old females. ${ }^{1)}$ Since induction of HSPs shows age-associated decline in certain species such as rats, ${ }^{6)}$ our data may reflect the increased ratio of old rotifer females in the stationary phase.

Our results about the expression change of HSP70 and GRP94 in concert with the population dynamics suggest that these stress proteins are useful molar markers for monitoring the population phases of the rotifer. However, it appears that the expression of HSPs is not directly related to the extension of lifespan in the rotifer, as mentioned before. ${ }^{3-4)}$ Further studies are necessary to disclose the mechanisms involved in the regulation of rotifer lifespan.

\section{ACKOWLEDGMENTS}

This study was partly supported by a Grant-in-Aid for Creative Scientific Research No. 12NP0201 from the Ministry of Education, Culture, Sports, Science and Technology of Japan. SK and TY were supported by Research Fellowships of the Japan Society for the Promotion of the Science for Young Scientists.

\section{REFERENCES}

1. Enesco HE. Rotifers in aging research: use of rotifers to test various theories of aging. Hydrobiologia 1993; 255/256: 59-70.

2. Yoshinaga $T$, Hagiwara A, Tsukamoto $K$. Why do rotifer populations present a typical sigmoid growth curve? Hydrobiologia 2001; 446/447: 99-105.

3. Tatar M, Khazaeli AA, Curtsinger JW. Cheperoning extended life. Nature 1997; 390: 30.

4. Shama S, Yung LC, Antoniazzi JM, Jiang JC, Jazwinski SM. Heat stress-induced life span extension in yeast. Exp. Cell Res. 1998; 245: 379-388.

5. Yoshinaga $T$, Hagiwara A, Tsukamoto K. Effect of conditioned media on the asexual reproduction of the monogonont rotifer Brachionus plicatilis 0 F. Müllar. Hydrobiologia 1999; 412: 103-110.

6. Heydari AR, Takahashi R, Gutsmann A, You $S$, Richardson A. Hsp70 and aging. Experientia 1994; 50: 1092-1098 